\title{
CHARGE syndrome
}

INSERM

\section{Source}

INSERM. (1999). Orphanet: an online rare disease and orphan drug data base. CHARGE syndrome. ORPHA:138

CHARGE syndrome is a multiple cong enital anomaly syndrome characterized by the variable combination of multiple anomalies, mainly Coloboma; Choanal atresia/stenosis; Cranial nerve dysfunction; Characteristic ear anomalies (known as the major 4 C's). 